\title{
The use of HEAVEN criteria to predict difficult laryngeal view and intubation failure with direct and video laryngoscopy
}

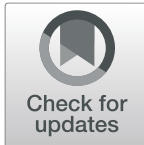

\author{
Ryan D. Henschell ${ }^{*}$ and Paul K. Miller
}

\section{To the Editor}

We read with interest the paper by Nausheen et al. [1] in which the authors report that the HEAVEN criteria [2] predict laryngoscopic view and intubation success for direct and video laryngoscopy. They conducted a retrospective analysis of 5137 patients who underwent rapid sequence induction (RSI) of anesthesia prior to intubation. In their study each of the HEAVEN criteria was associated with lower intubation success rates with and without desaturation, and the total number of HEAVEN criteria present was inversely proportional to intubation success with and without desaturation.

Nausheen et al. report that as the number of HEAV EN criteria increases, the difficulty of laryngoscopy increases. But we are perplexed as to why the presence of three criteria confers less difficulty than the presence of two.

The authors also report that air medical crews applied the HEAVEN screening tool prior to RSI, and if one or more criteria were present, the crews were encouraged to use alternative (intubation) strategies. We wonder why strategic positioning of the patients prior to attempted laryngoscopy/intubation was not included. Optimal positioning of an obese patient has been shown to improve the ease of laryngoscopy and intubation [3].

Additionally, it strikes us as odd that, in Fig. 1, the physiologic phenomenon of "exsanguination" negatively impacts the direct laryngoscopic (DL) and video laryngoscopic $(\mathrm{VL})$ views of the airway more than the physical phenomena of extremes of size, vomit/blood/fluid in the pharynx and neck mobility issues, as well as VL in

\footnotetext{
* Correspondence: ryan.henschell@rvu.edu

Rocky Vista University - College of Osteopathic Medicine, 8401 S Chambers Rd, Parker, CO 80134, USA
}

(c) The Author(s). 2020 Open Access This article is licensed under a Creative Commons Attribution 4.0 International License, which permits use, sharing, adaptation, distribution and reproduction in any medium or format, as long as you give appropriate credit to the original author(s) and the source, provide a link to the Creative Commons licence, and indicate if changes were made. The images or other third party material in this article are included in the article's Creative Commons licence, unless indicated otherwise in a credit line to the material. If material is not included in the article's Creative Commons licence and your intended use is not permitted by statutory regulation or exceeds the permitted use, you will need to obtain permission directly from the copyright holder. To view a copy of this licence, visit http://creativecommons.org/licenses/by/4.0/. The Creative Commons Public Domain Dedication waiver (http://creativecommons.org/publicdomain/zero/1.0/) applies to the data made available in this article, unless otherwise stated in a credit line to the data.

patients with anatomic challenges. Similarly strange is that direct and video laryngoscopy in hypoxemic $\left(\mathrm{SpO}_{2} \leq 93 \%\right)$ patients are as difficult as in patients with "clinically significant" vomit/blood/fluid in their mouths and throats.

Table 2 reveals, that in spite of the difficult airway views noted in patients with hypoxemia or exsanguination, there was no statistically significant association of such views with failure at first intubation attempt utilizing either DL or VL. With respect to failure of first intubation attempt without desaturation, there was no statistically significant correlation of VL in the setting of exsanguination.

It is not surprising that four of the six HEAVEN criteria (extremes of size, anatomic challenges, vomit/ blood/fluid, neck mobility issues) are associated with difficult laryngoscopy and intubation. But it appears that the inclusion of two purely physiologic parameters (exsanguination, hypoxemia) produces curious results.

We invite the authors to respond to these comments.

\section{Authors' contributions \\ $\mathrm{RDH}$ and PKM wrote and revised the manuscript. All authors have read and approved the final manuscript.}

\section{Funding}

Not applicable.

\section{Availability of data and materials}

analyzed during the current work.

Ethics approval and consent to participate

Not applicable.

Consent for publication

Not applicable.

Competing interests

The authors declare that they have no competing interests. 
Received: 29 September 2020 Accepted: 2 November 2020

Published online: 11 November 2020

\section{References}

1. Nausheen F, Niknafs NP, MacLean DJ, Olvera DJ, Wolfe AC Jr, Pennington

TW, Davis DP. The HEAVEN criteria predict laryngoscopic view and

intubation success for both direct and video laryngoscopy: a cohort analysis. Scand J Trauma Resusc Emerg Med. 2019;27(1):50.

2. Kuzmack E, Inglis T, Olvera D, Wolfe A, Seng K, Davis D. A novel difficult airway prediction tool for emergency airway management: validation of the HEAVEN criteria in a large air medical cohort. J Emerg Med. 2017;54(4):395-401.

3. Brodsky JB, Lemmens HJM, Brock-Utne JG, Saidman LJ, Levitan R. Anesthetic considerations for bariatric surgery: proper positioning is important for laryngoscopy. Anesth Analg. 2003;96(6):1841-2.

\section{Publisher's Note}

Springer Nature remains neutral with regard to jurisdictional claims in published maps and institutional affiliations.

Ready to submit your research? Choose BMC and benefit from:

- fast, convenient online submission

- thorough peer review by experienced researchers in your field

- rapid publication on acceptance

- support for research data, including large and complex data types

- gold Open Access which fosters wider collaboration and increased citations

- maximum visibility for your research: over 100M website views per year

At BMC, research is always in progress.

Learn more biomedcentral.com/submissions 